\title{
Original article (short paper) \\ Contrasting morphology and training background in waterpolo teams of different competitive levels
}

\author{
Sofia Canossa \\ University of Porto, Portugal \\ José Arturo Abraldes \\ University of Murcia, Spain \\ Susana Soares \\ University of Porto, Portugal \\ María Helena Vila \\ University of Vigo, Spain \\ Carmen Ferragut \\ University of Alcalá, Spain \\ Nuria Rodríguez \\ Catholic University of Murcia, Spain \\ Francisco Manuel Argudo \\ Autonomous University of Madrid, Spain \\ Ricardo Jorge Fernandes \\ Júlio Manuel Garganta \\ University of Porto, Portugal
}

\begin{abstract}
We aimed to describe and compare the general morphological, somatotype and training background characteristics of Iberian waterpolo players (22 Portuguese and 22 Spanish National Teams players) considering their playing positions. The International Working Group of Kinanthropometry guidelines was herein followed, and a somatochart was obtained through specific software (Somatotype, Calculation and Analysis. (O2001 SWEAT technologies). Spanish players train more hours per week ( $22.8 \pm 9.5 v s .12 .2 \pm 5.6)$, are taller $(187.4 \mathrm{~cm} \pm 6.6 v s .180 .3 \mathrm{~cm} \pm 5.1)$, heavier (89.2 kg $\pm 11.6 v s .79 .1 \mathrm{~kg} \pm 10.0)$, show higher arm span $(195.7 \mathrm{~cm} \pm 8.5 v s .185 .2 \mathrm{~cm} \pm 7.4)$ and muscle mass percentage $(49.0 \% \pm 1.8 v s .46 .0 \% \pm 6.0)$, and tend to be more mesomorphic $(5.19 \pm 1.27 v s .4 .26 \pm 1.32)$ than the Portuguese players. Concerning field positions, Spanish center forward players train more hours per week than the Portuguese $(20.2 \pm 9.1$ $v s .12 .2 \pm 3.8)$ and show higher arm span $(204.4 \mathrm{~cm} \pm 7.3 v s .184 .0 \mathrm{~cm} \pm 6.5)$. Spanish goal keepers and outside players show higher muscle mass percentage $(49.8 \% \pm 1.5 v s .42 .2 \% \pm 5.2$ and $49.4 \% \pm 1.5 v s .45 .5 \% \pm 4.6$, respectively) than the Portuguese players. These evidences should be taken into account for the improvement of waterpolo sport.
\end{abstract}

Keywords: high performance, elite players, selection criteria

Resumo- "Comparação de indicadores morfológicos e do tempo de treino semanal em equipes de pólo aquático de diferentes níveis competitivos." O presente estudo objetivou descrever e comparar a morfologia geral, o somatótipo e horas de treino de jogadores Ibéricos de selecções nacionais de polo aquático (22 portugueses e 22 espanhóis) e compará-los quanto às posições de jogo. Utilizou-se um software específico para o desenho da somatocarta (Somatotype, Calculation and Analysis, (2001 SWEAT technologies). Os jogadores espanhóis, quando comparados com os portugueses, treinam mais horas por semana $(22,8 \pm 9,5 v s .12,2 \pm 5,6)$, são mais altos $(187,4 \mathrm{~cm} \pm 6,6 v s .180,3 \mathrm{~cm} \pm 5,1)$, mais pesados $(89,2 \mathrm{~kg}$ $\pm 11,6$ vs. $79,1 \mathrm{~kg} \pm 10,0$ ), apresentam maior envergadura (195,7 $\mathrm{cm} \pm 8,5 \mathrm{vs.} 185,2 \mathrm{~cm} \pm 7,4)$, percentagem de massa muscular 
$(49,0 \% \pm 1,8 v s .46,0 \% \pm 6,0)$ e tendem a ser mais mesomorfos $(5,19 \pm 1,27$ vs. 4,26 $\pm 1,32)$ do que os jogadores portugueses. Quanto às posições de jogo, os pivôs espanhóis treinam mais horas por semana $(20,2 \pm 9,1$ vs. 12,2 $\pm 3,8)$ e apresentam maior envergadura $(204,4 \mathrm{~cm} \pm 7,3 \mathrm{vs} .184,0 \mathrm{~cm} \pm 6,5)$ que os portugueses. Ainda, respectivamente, os goleiros e os jogadores laterais espanhóis apresentam percentagens mais elevadas de massa muscular $(49,8 \% \pm 1,5$ vs.42,2\% $\pm 5,2$ e 49,4\% $\pm 1,5$ $v s .45,5 \% \pm 4,6)$ do que os portugueses. Estas evidências devem ser consideradas para a melhoria do polo aquático.

Palavras-chave: alto rendimento, jogadores de elite, critérios de seleção

\begin{abstract}
Resumen - "Comparación de indicadores morfológicos y de tiempo de entrenamiento semanal en equipos de waterpolo de diferentes niveles competitivos" El objetivo del estudio fue describir y comparar la morfología general, somatotipo y horas de entrenamiento de jugadores Ibéricos de selecciones nacionales de waterpolo (22 portugueses y 22 españoles) y comparar sus diferencias entre posiciones de juego. Los parámetros evaluados fueron seleccionados en la literatura. La somatocarta fue construida con un software específico (Somatotype, Calculation and Analysis, C2001 SWEAT technologies). Los jugadores españoles entrenan más horas por semana $(22,8 \pm 9,5$ vs.12,2 $\pm 5,6)$, tienen más altura $(187,4 \mathrm{~cm} \pm 6,6$ vs. 180,3 $\mathrm{cm} \pm 5.1)$, más peso $(89,2 \mathrm{~kg} \pm 11,6 v s .79,1 \mathrm{~kg} \pm 10,0)$, más envergadura $(195,7 \mathrm{~cm} \pm 8,5 v s$. $185,2 \mathrm{~cm} \pm 7,4)$, porcentaje de masa muscular $(49,0 \% \pm 1,8 \mathrm{vs} .46,0 \% \pm 6,0)$ y tienden a presentar valores más altos de mesomorfia $(5,19 \pm 1,27$ vs. 4,26 $\pm 1,32)$ que los jugadores portugueses. Con respecto a las posiciones de juego, los boyas Españoles superan los portugueses en las horas de entrenamiento semanal $(20,2 \pm 9,1$ vs. $12,2 \pm 3,8)$ y presentan más envergadura $(204,4 \mathrm{~cm} \pm 7,3 v s .184,0 \mathrm{~cm} \pm 6,5)$. Los porteros y jugadores periféricos españoles tienen más masa muscular que los jugadores portugueses $(49,8 \% \pm 1,5$ vs. $42,2 \% \pm 5,2$ e $49,4 \% \pm 1,5$ vs.45,5\% $\pm 4,6)$, respectivamente. Estas evidencias deberán ser consideradas para la mejora del waterpolo.
\end{abstract}

Palabras clave: alto rendimiento, jugadores de elite, criterios de selección

\section{Introduction}

Waterpolo is a multi-faceted and high-intensity intermittent team sport in which actions under hard conditions of body contact with the opponent are predominant (Lozovina, Durović, \& Katić, 2009). Thus, the anthropometric and strength characteristics are very important for the success in this sport (Lozovina \& Pavičić, 2004). It is recognized that the anthropometric characteristics of elite waterpolo players have changed in the past 15 years (Dopsaj \& Aleksandrović, 2009). This information is essential for the knowledge of this sport and its evolution, as well as to set up references about the physical characteristics of the most successful players (Dopsaj \& Aleksandrović, 2009; Lozovina \& Pavičić, 2004). It is important to know whether players on teams of lower competitive level are different in their physical characteristics and somatotypes in comparison with elite players. This information could help players on such teams by making them aware of their weaknesses. Also, it could be helpful to coaches who are planning training programs.

Despite the existing literature about anthropometrical characteristics of waterpolo players (Aleksandrović, Naumovski, Radovanović, Georgiev \& Popovski, 2007; Carter \& Ackland, 1994; Dopsaj \& Aleksandrović, 2009; Lozovina et al., 2009; Lozovina \& Pavičić, 2004; Tsekouras et al., 2005), scientific studies about morphological differences among distinct teams of different countries and competitive levels are scarce. Researchers are in search of definition of characteristics and qualities concerning elite waterpolo players that may be related to the success of winning teams (Escalante, Saavedra, \& Mansilla, 2011; Falk, Lidor, Lander, \& Land, 2004; Lupo, Tessitore, Minganti, \& Capranica, 2010). Specifically, particular skills and physical demands that each specific role requires in the game have been the focus of researchers
(Platanou \& Geladas, 2006; Tsekouras et al., 2005). Nowadays, it is already recognized that the physical characteristics of the players differ according to their role performed in the field (Dopsaj \& Aleksandrović, 2009; Drinkwater \& Mazza, 1994; Falk et al., 2004; Lozovin, et al., 2009), and that the years of competitive experience and training promote morphological adaptations that lead to those differences (Aleksandrović et al., 2007; Lozovina et al., 2009). Furthermore, physical parameters and physical profile help coaches to better plan training protocols and also establish references for amateurs and semi-professionals in young talent detection programs (Lima, Sigwalt, Rech, \& Petroski, 2007). In fact, physical differences between players in their specific playing positions are so important that, for efficient modern waterpolo game, it is required to select the players according to some of those physical characteristics (Dopsaj \& Aleksandrović, 2009).

Waterpolo is a sport with a complex expression of all physical features of human body and, in comparison to other team sports, waterpolo players belong to a category of athletes with an expressive body height. Also, they tend to be taller and more muscular than other aquatic athletes, except those short distance sprint swimmers (Dopsaj \& Aleksandrović, 2009). Following these authors, regarding specialized positions and their differences, goalkeepers are on the average the tallest $(198.18 \pm 1.66 \mathrm{~cm})$, center back $(\mathrm{CB})$ and forward $(\mathrm{CF})$ players have higher body surface area (194.51 $\pm 4.16 \mathrm{~cm}^{2}$ and $203.86 \mathrm{~cm}^{2} \pm 4.16$, respectively) and are taller (192.45 $\mathrm{cm} \pm 1.66$ and $195.75 \mathrm{~cm} \pm 1.66$, respectively) than peripheral or outside players $\left(185.83 \mathrm{~m}^{2} \pm 2.83\right.$ of body surface area and $190.28 \mathrm{~cm} \pm 1.13$ ). In addition, whereas all players on average has expressed a body mass index (BMI) between 25.25 e $26.85 \mathrm{~kg} / \mathrm{m}^{2}$, the $\mathrm{CB}$ and CF players tend to show the highest values within playing positions $\left(26.48 \mathrm{~kg} / \mathrm{m}^{2} \pm 0.83\right.$ and $27.20 \mathrm{~kg} /$ $\mathrm{m}^{2} \pm 0.83$, respectively). Lozovina et al. (2009) found that center 
players showed very high results in all anthropometric variables used to detect body mass and volume. Center players belong to a category of very muscular or even overweight people, and their dimensions and body characteristics give them some sort of advantage when performing their roles in the game (Dopsaj \& Aleksandrović, 2009). Information about players of lower ranking teams is still scarce. In fact, comparisons between these lower rank players with top level players in regard the physical characteristics and specialized positions, are unknown. This is the case among waterpolo players from Portugal and Spain, two historically and geographically close countries from the Iberian Peninsula, with different waterpolo competitive levels. The Spanish men's national team was vice World Champion in 2009, and the Portuguese national team was unable to qualify for the final tournament of Europe Championship in 2008. Given these facts, in the current study it was hypothesized that the two group's differences in morphology and training background characteristics would help to explain their different competitive level.

Considering the lack of information about the morphology and training background characteristics of different level waterpolo teams, the aim of the present study was twofold: i) to describe and compare general morphological and training background characteristics of players from Spanish and Portuguese waterpolo national teams, considering their specialized playing position and as a whole; ii) to describe and compare the somatotype characteristics of players from the Spanish and Portuguese waterpolo national teams, considering their specialized playing position and as a whole. Additionally, the relevant morphological characteristics required for selecting male waterpolo players will be highlighted.

\section{Methods}

The experimental protocol used in our study was adopted by the Spanish group of kinanthropometry, is in accordance to the Declaration of Helsinki and was approved by the Institutional Review Committee of the Universidad Católica San António de Murcia, Spain (\#F-PR-AC-05-01-05 on April 14, 1998).

\section{Sample}

Forty-four injury free male waterpolo players were recruited from the Spanish and Portuguese national teams. Two different groups were established, one with Spanish players $(n=22)$, ages between 19 and 31 years $(24.9 \pm 5.9)$, and the other with Portuguese players $(n=22)$, ages between 21 and 32 years $(26.4$ \pm 5.3 ). Players and coaches were informed about the procedures of the experimental protocol and written informed consent was signed by the participants.

\section{Measures}

Players provided information regarding their practice experience and training hours per week, which was hand noted and confirmed by their coaches and official registration in the respective National Federations. The parameters concerning description of morphologic and training background characteristics of the players were in accordance with the specialized literature (Aleksandrovic et al., 2007; Dopsaj \& Aleksandrović, 2009; Falk et al., 2004; Lozovina et al., 2009; Lozovina \& Pavičić, 2004; Melchiorry et al., 2010; Tsekouras et al., 2005). For the anthropometrical assessment, norms and techniques were followed according the International Working Group of Kinanthropometry (Ross \& Marfell-Jones, 1991). The anthropometrical parameters were selected according Carter and Ackland (1994) for Kinanthropometry in aquatic sports and as determinant for sport performance in waterpolo (Aleksandrovic et al., 2007; Carter \& Marfell-Jones, 1994; Dopsaj \& Aleksandrović, 2009; Drinkwater \& Mazza, 1994; Lozovina et al., 2009): (i) hand and foot length, body mass, body height and arm span, measured with a scale and a stadiometer (Seca, Germany); (ii) biiliocristal, biacromial, femur, humerus, and wrist breadths, measured with a paquimeter (Holtain Ltd., United Kingdom); (iii) ankle, calf, thigh (upper and middle), gluteus, waist, chest, wrist, arm (relaxed, and flexed and tensed) and forearm girths, assessed through an inextensible fiberglass tape measure (Holtain Ltd., United Kingdom); (iv) subscapular, triceps, supraspinale, pectoral, middle thigh, abdominal, medial calf, bicipital, axilar and iliac crest skinfolds, assessed through a skinfold caliper (Holtain Ltd., United Kingdom), allowing the determination of six body composition related parameters - the muscle mass percentage (Martin et al., 1990), the fat percentage (Yuhasz, 1974 ), the body mass index (BMI), and the somatotype (Carter \& Marfell-Jones, 1994).

\section{Procedures}

Players were grouped within their national team, according to specialized playing positions (three goal keepers, five center forwards, five center back and nine outside or peripheral players) and were tested during a training session with the same testing equipment and methodology.

\section{Analysis}

Means plus standard deviations were calculated for all variables to conduct the descriptive data analysis. Due to the low number of subjects available by specialized playing position, comparisons were performed using the non-parametric Mann-Whitney test for independent samples. A significance level of 5\% was accepted.

\section{Results}

Morphologic and training background characteristics of the Spanish and Portuguese waterpolo players (team as a whole, and specialized playing positions) are presented in Table 1. It is possible to verify that: (i) the Spanish and Portuguese players have similar age and years of sport experience (with exception for the center backs); (ii) Spanish players presented higher number of training hours per week, or $53.5 \%$ more than Portuguese players $(p=.000)$. This was also detected for all field positions, although for the goalkeepers only a tendency 
was observed; (iii) Spanish players are taller $(3.8 \% ; p=.000)$, heavier $(11.3 \% ; p=.002)$, show higher arm span $(5.4 \%$; $p=.000)$ and muscle mass percentage than the Portuguese counterparts $(6.3 \% ; p=.021)$. Differences are also observed on center forwards, regarding body height $(6.9 \% ; p=.009)$ and arm span $(10.0 \% ; p=.009)$; goal keepers and outside players, as for the muscle mass percentage $(15.3 \%$; $p=.050$ and $7.9 \%$; $p=.042$, respectively); (iv) players from both countries present similar fat percentage and body mass index.

Table 2 shows the means plus standard deviations values regarding the somatotype components of the Spanish and Portuguese waterpolo players, for the whole team and by specialized playing position; this information is complemented by the somatochart displayed in Figure 1.

Both Spanish and Portuguese waterpolo players are classified as endo-mesomorphs (2.9-5.2-2.2 and 2.9-4.3-2.3 respectively). Spanish players show a tendency to be more mesomorphic than Portuguese players, with values higher for the whole team $(5.19 \pm 1.27 v s .4 .26 \pm 1.32)$ and for each player's position, as is shown in the Table 2. Base on the players' position of the Spanish team, the classification varies between endo-mesomorphs (back and forward players) and balanced mesomorphs (outside players and goalkeepers). Conversely, although with dominant mesomorphic component, Portuguese players vary more. Some players also display an important evidence of ectomorphic component (particularly the goalkeepers, classified as ectomesomorphs), and the center Portuguese players varies as endo-mesomorphs and balanced mesomorphs (in the forward and back position, respectively).

Table1. Mean \pm SD values of the morphology and training background characteristics of Spanish and Portuguese waterpolo players for the total sample and by specialized playing position.

\begin{tabular}{|c|c|c|c|c|c|c|c|c|c|c|}
\hline \multirow{2}{*}{$\begin{array}{l}\begin{array}{l}\text { Playing } \\
\text { position }\end{array} \\
\text { Group }\end{array}$} & \multicolumn{2}{|c|}{ Goalkeepers $(n=6)$} & \multicolumn{2}{|c|}{ Center back $(n=10)$} & \multicolumn{2}{|c|}{ Center forward $(n=10)$} & \multicolumn{2}{|c|}{ Outside $(n=18)$} & \multicolumn{2}{|c|}{ All players $(n=44)$} \\
\hline & $\begin{array}{c}\text { Spanish } \\
(n=3)\end{array}$ & $\begin{array}{l}\text { Portuguese } \\
\quad(n=3)\end{array}$ & $\begin{array}{c}\text { Spanish } \\
(n=5)\end{array}$ & $\begin{array}{l}\text { Portuguese } \\
\quad(n=5)\end{array}$ & $\begin{array}{c}\text { Spanish } \\
(n=5)\end{array}$ & $\begin{array}{l}\text { Portuguese } \\
\quad(n=5)\end{array}$ & $\begin{array}{c}\text { Spanish } \\
(n=9)\end{array}$ & $\begin{array}{l}\text { Portuguese } \\
\quad(n=9)\end{array}$ & $\begin{array}{c}\text { Spanish } \\
(n=22)\end{array}$ & $\begin{array}{c}\text { Portuguese } \\
\quad(n=22)\end{array}$ \\
\hline Age (yr) & $31.0 \pm 6.1$ & $23.7 \pm 3.1$ & $21.4 \pm 1.6^{*}$ & $31.4 \pm 7.3$ & $24.8 \pm 7.4$ & $25.2 \pm 4.1$ & $25.1 \pm 4.9$ & $25.1 \pm 3.9$ & $24.9 \pm 5.9$ & $26.4 \pm 5.3$ \\
\hline $\begin{array}{l}\text { Experience } \\
\text { (yr) }\end{array}$ & $16.7 \pm 5.8$ & $10.7 \pm 2.1$ & $10.2 \pm 1.1$ & $16.4 \pm 8.1$ & $12.8 \pm 4.9$ & $13.2 \pm 5.2$ & $12.9 \pm 2.8$ & $11.7 \pm 3.1$ & $12.8 \pm 3.8$ & $12.9 \pm 5.1$ \\
\hline $\begin{array}{l}\text { Training } \\
\text { (h/wk) }\end{array}$ & $21.2 \pm 12.9$ & $13.2 \pm 1.6$ & $28.6 \pm 10.3^{*}$ & $11.0 \pm 4.1$ & $20.2 \pm 9.1 *$ & $12.2 \pm 3.8$ & $21.7 \pm 8.4^{*}$ & $12.5 \pm 8.1$ & $22.8 \pm 9.5^{*}$ & $12.2 \pm 5.6$ \\
\hline $\begin{array}{l}\text { Height } \\
(\mathrm{cm})\end{array}$ & $189.7 \pm 1.2$ & $181.8 \pm 8.3$ & $186.72 \pm 2.9$ & $182.7 \pm 3.4$ & $192.1 \pm 4.4^{*}$ & $178.8 \pm 4.7$ & $184.4 \pm 8.7$ & $179.4 \pm 5.2$ & $187.4 \pm 6.6^{*}$ & $180.3 \pm 5.1$ \\
\hline $\begin{array}{l}\text { Weight } \\
(\mathrm{kg})\end{array}$ & $85.8 \pm 7.00$ & $72.9 \pm 7.9$ & $91.4 \pm 10.2$ & $79.5 \pm 6.6$ & $102.3 \pm 11.0$ & $87.1 \pm 14.7$ & $82.0 \pm 7.4$ & $76.6 \pm 7.5$ & $89.2 \pm 11.6^{*}$ & $79.1 \pm 10.0$ \\
\hline $\begin{array}{l}\text { ArmSpan } \\
(\mathrm{cm})\end{array}$ & $194.3 \pm 3.5$ & $183.8 \pm 6.4$ & $192.80 \pm 6.1$ & $184.9 \pm 6.6$ & $204.4 \pm 7.3^{*}$ & $184.0 \pm 6.5$ & $193.0 \pm 9.0$ & $186.4 \pm 9.4$ & $195.7 \pm 8.5^{*}$ & $185.2 \pm 7.4$ \\
\hline G (\%) & $11.1 \pm 0.7$ & $9.6 \pm 1.3$ & $11.0 \pm 1.9$ & $10.8 \pm 2.8$ & $12.7 \pm 2.6$ & $13.3 \pm 2.8$ & $10.1 \pm 1.3$ & $10.4 \pm 2.1$ & $11.0 \pm 1.9$ & $11.0 \pm 2.6$ \\
\hline MM (\%) & $49.8 \pm 1.5^{*}$ & $42.2 \pm 5.2$ & $49.4 \pm 1.5$ & $46.3 \pm 2.9$ & $47.6 \pm 2.3$ & $48.7 \pm 9.8$ & $49.4 \pm 1.5^{*}$ & $45.5 \pm 4.6$ & $49.0 \pm 1.8^{*}$ & $46.0 \pm 6.0$ \\
\hline $\begin{array}{l}\text { BMI } \\
\left(\mathrm{kg} / \mathrm{cm}^{2}\right)\end{array}$ & $23.9 \pm 1.9$ & $22.0 \pm 1.0$ & $26.3 \pm 3.4$ & $23.8 \pm 1.4$ & $27.7 \pm 2.3$ & $27.1 \pm 3.4$ & $24.1 \pm 1.0$ & $23.8 \pm 2.4$ & $25.4 \pm 2.5$ & $24.3 \pm 2.8$ \\
\hline
\end{tabular}

Age $(\mathrm{yr})=$ age of the players in years; Experience $(\mathrm{yr})=$ experience in sport, in years; Training $(\mathrm{h} / \mathrm{wk})=$ number of training hours per week; Height $(\mathrm{cm})=$ height of the players in centimeters; Weight $(\mathrm{kg})=$ weight of the players in kilograms; ArmSpan $(\mathrm{cm})=$ arm span length in centimeters; G $(\%)=$ players fat percentage; MM $(\%)=$ players muscle mass percentage; BMI = body mass index of the players $\left(\mathrm{kg} / \mathrm{cm}^{2}\right)$

*Represents significant differences between teams $(p<.05)$.

Table 2. Mean \pm SD values of each somatotype components of Spanish and Portuguese waterpolo players for the total sample and by specialized playing position.

\begin{tabular}{|c|c|c|c|c|c|c|c|c|c|c|}
\hline & \multicolumn{2}{|c|}{ Goalkeepers $(n=6)$} & \multicolumn{2}{|c|}{ Center back $(n=10)$} & \multicolumn{2}{|c|}{ Center forward $(n=10)$} & \multicolumn{2}{|c|}{ Outside $(n=18)$} & \multicolumn{2}{|c|}{ All players $(n=44)$} \\
\hline & $\begin{array}{c}\text { Spanish } \\
(n=3)\end{array}$ & $\begin{array}{l}\text { Portuguese } \\
\quad(n=3)\end{array}$ & $\begin{array}{c}\text { Spanish } \\
(n=5)\end{array}$ & $\begin{array}{l}\text { Portuguese } \\
\quad(n=5)\end{array}$ & $\begin{array}{c}\text { Spanish } \\
(n=5)\end{array}$ & $\begin{array}{l}\text { Portuguese } \\
\quad(n=5)\end{array}$ & $\begin{array}{l}\text { Spanish } \\
(n=9)\end{array}$ & $\begin{array}{l}\text { Portuguese } \\
\quad(n=9)\end{array}$ & $\begin{array}{c}\text { Spanish } \\
(n=22)\end{array}$ & $\begin{array}{c}\text { Portuguese } \\
\quad(n=22)\end{array}$ \\
\hline Endomorphy & $3.00 \pm 0.50$ & $2.20 \pm 0.08$ & $3.00 \pm 1.00$ & $2.63 \pm 0.67$ & $3.55 \pm 0.86$ & $3.96 \pm 1.29$ & $2.46 \pm 0.53$ & $2.73 \pm 1.12$ & $2.91 \pm 0.81$ & $2.91 \pm 1.12$ \\
\hline Mesomorphy & $4.74 \pm 0.80$ & $3.59 \pm 0.98$ & $5.28 \pm 1.89$ & $4.58 \pm 0.55$ & $5.70 \pm 0.67$ & $4.79 \pm 2.13$ & $5.01 \pm 1.33$ & $4.02 \pm 1.19$ & $5.19 \pm 1.27$ & $4.26 \pm 1.32$ \\
\hline Ectomorphy & $2.80 \pm 0.73$ & $3.31 \pm 0.67$ & $1.95 \pm 1.29$ & $2.55 \pm 0.56$ & $1.59 \pm 0.81$ & $1.30 \pm 0.83$ & $2.51 \pm 0.72$ & $2.43 \pm 1.03$ & $2.22 \pm 0.94$ & $2.32 \pm 1.02$ \\
\hline
\end{tabular}



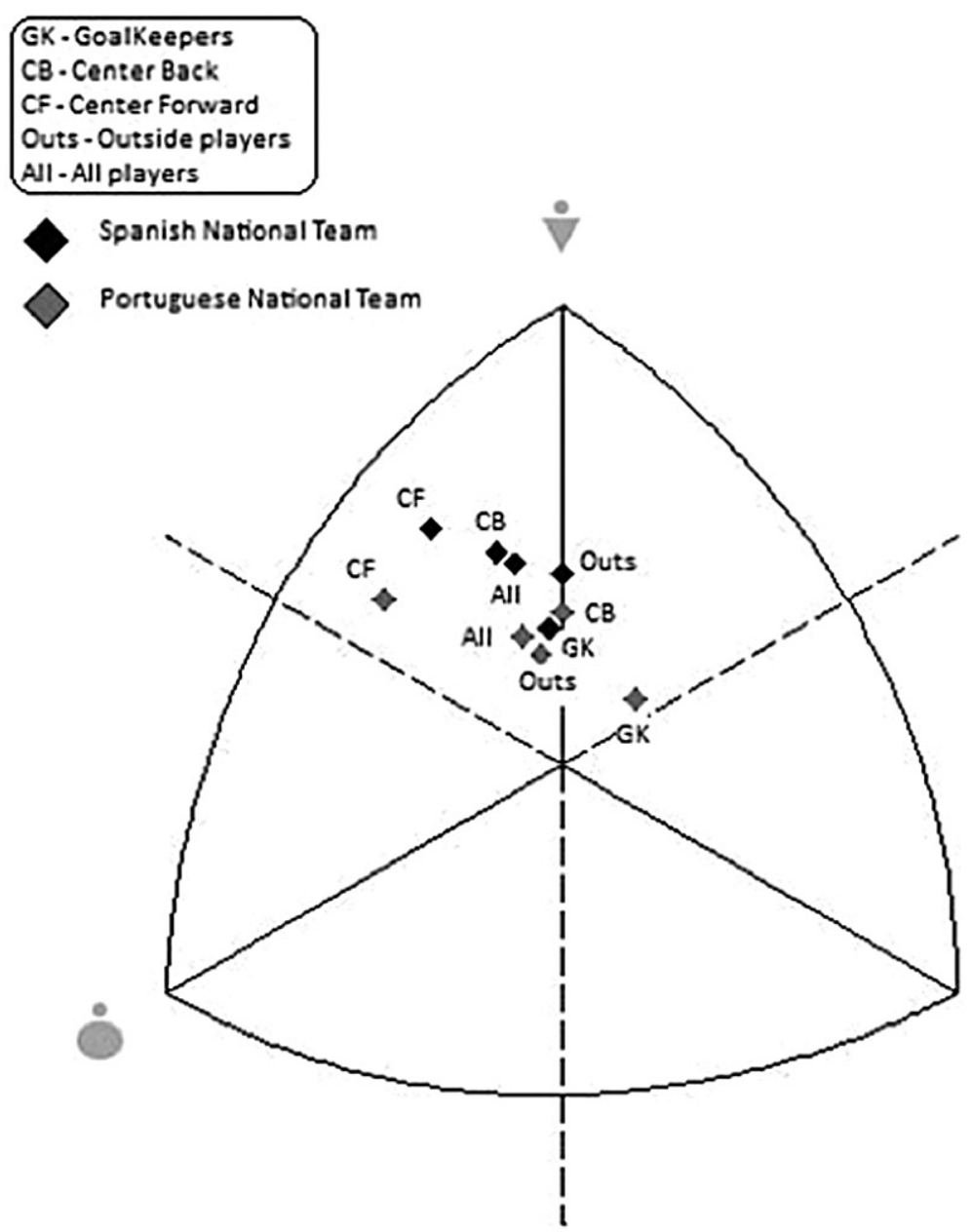

Figure 1. Somatochart of waterpolo players from Spanish and Portuguese national teams by specialized playing positions and for the total sample (all players).

\section{Discussion}

The similarity found regarding the age and years of sport experience of both groups suggests that Portuguese players need a longer period of learning time and development, to be able to perform adequately at international level. Moreover, both Spanish and Portuguese players age values are in accordance with other elite national teams as Serbia and Greece (Dopsaj \& Aleksandrović, 2009; Tsekouras et al., 2005). However, their sport experience is lower than Serbian national team players (Dopsaj \& Aleksandrović, 2009), the actual bronze medalists in the Olympic Games in 2012, evidencing the importance of competitive experience in this sport. This can be seen in the Portuguese group regarding the center back position, as they tend to be more experienced and older than their Spanish counterparts. This means that they need to have more experience and maturity to neutralize strong center forwards from international level. It is well known that center back players organize tactical actions, hold the ball for longer time than other field positions, and their role is vital for the flow of the game, therefore, experience is required (Dopsaj \& Aleksandrović, 2009; Hughes, Appleton, Brooks, Hall, \& Wyatt, 2006). The Spanish goalkeepers' tendency to be older and have more sport experience than Portuguese goalkeepers, (i.e., 10 years difference) are aspects that may explain why the national Portuguese team would face more difficulties when playing against elite teams, such as the Spanish team. Moreover, Portuguese goalkeepers seem to be younger than other counterparts mentioned in the literature, such as the case of the eight goalkeepers from first division clubs (Platanou, 2009). Spanish goalkeepers' values are similar to those found in the literature. Kačić (2007) claim that goalkeepers have one of the most demanding roles in a team, and their tactical maturity adds to other qualities which can be crucial to their success.

Regarding the number of training hours per week, Portuguese players likely fall back in their development and performance as their time spent practicing the sport is around $14.5 \mathrm{~h}$ per week (see SD values). Although the Portuguese values seems to be similar to the Italian senior teams and junior national team (13 h per week), as reported by Melchiorry et al. (2010), it is unknown if that information includes strength training sessions outside the pool. In addition, Portuguese players tend to surpass in three hours the values reported for Syrian players, ages 13 and 14 years (Donev et al., 2009).

With regard the field positions of play, differences of practice time between Portuguese and Spaniards were also found (although for the goalkeepers only a tendency was observed). Spanish 
center players (forward and back) practice $13 \mathrm{~h}$ up to $23.8 \mathrm{~h}$ per week. It is well known that the practice time for center players is crucial, given the high dependence of the waterpolo game in those roles (Hughes et al., 2006). Moreover, over the years of practice, the sport activity with long periods of weekly work affects the anthropometric structure and learnt motor skills, especially for the center players that usually outstand from other field players due to their physical characteristics (Aleksandrović et al., 2007). As stated by some researchers, the time of practice and the specific characteristics of the waterpolo itself are considered reasons for anthropometric differences between groups (Aleksandrović et al., 2007; Falk et al., 2004; Lozovina et al., 2009). Even though the scarcity of data regarding the time of practice by waterpolo teams in general, which would allow a better discussion on this subject, the disparity found between the two teams clarifies some of the reasons for their difference in competitive level.

Regarding body height, body mass, arm span and muscle mass percentage, since Portuguese group shows lower values than their Spanish counterparts, the differences found points out a morphological distinction between them.Given the relevance of physical contact in this sport, the lower muscle mass of the Portuguese players would likely result in disadvantages when playing against the Spanish team (Dopsaj et al., 2007, Lozovina et al., 2009; Platanou \& Geladas, 2006). Furthermore, Spaniards body height and mass are similar to those reported in the literature for elite waterpolo players, whereas Portuguese values are lower than those reported in other studies (Garbolewski \& Starosta, 2002; Lozovina \& Pavičić, 2004). They are lower than the data found by Dopsaj and Aleksandrović (2009) for senior top players from several countries (Hungary, Australia, Croatia, Greece and Serbia). Serbian players had the highest body height and mass (193.29 cm; $96.17 \mathrm{~kg})$. Additionally, the height and weight of Portuguese players are the lowest results found in comparison to results from the last decade reported by Drinkwater and Mazza (1994). These authors report that senior players were $180 \mathrm{~cm}$ and $80 \mathrm{~kg}$. Portuguese players show lower values than junior elite players (Dopsaj \& Thanopoulos, 2006; Melchiorry et al., 2010) and other national players (Garbolewski \& Starosta, 2002; Lozovina et al., 2009; Platanou \& Geladas, 2006).

With regard specific playing positions, Portuguese goalkeepers reveal lower muscle mass and a tendency for lower arm span than Spaniards. Their values, as well the body height and mass, tend to be lower than what is found in the literature for top goalkeepers (Kačić, 2007). It is well known that, for those specific players, having bigger arm span and body height is a physical advantage regarding goal defense (Dopsaj \& Aleksandrović, 2009). In addition, in the positions of center players, Spaniards tend to surpass Portuguese values of body mass in $15 \mathrm{~kg}$. Taken together with the already pointed out significant higher training time, body mass may be crucial for Portuguese to improve performance in that role. Center players belong to a category of very muscular or even overweight people, and their height and large body volume are considered an advantage for performance efficiency (Dopsaj \& Aleksandrović, 2009; Huges et al., 2006; Lozovina \& Pavičić, 2004). In fact, their activity profile justifies the high values found for all the parameters considered in the present study.
Spanish center forward players body height and mass are in accordance with the literature reporting elite players (Dopsaj \& Aleksandrović, 2009), whereas Portuguese values tend to be lower, not only regarding elite players but also regarding players of national level (Geladas, 2006). In the Dopsaj and Aleksandrović (2009)'s research, center forwards were the players with the highest body mass average $(104.17 \mathrm{Kg})$. This is an important factor for wrestling (Dopsaj \& Aleksandrović, 2009; Huges et al., 2006; Platanou, 2004), considering that center back defense players inflict the majority of fouls, with resulting temporary exclusions, against the center forwards. Such exclusions create numeric inferiority (i.e., man-up) for the defending team. For these researchers, center forward players have a privileged central location to score, being responsible for more than $50 \%$ of the earned scores of the team. Such facts confirm that these players need to be heavier and bulkier (Lozovina et al., 2009). In turn, center back opponents must have physical capacity to neutralize them (Platanou, 2004) and, in the present study, Spanish center backs show similar values to those reported in the literature, whereas Portuguese center backs tend to be lighter than Spaniards. Furthermore, Portuguese center backs values of body height and mass tend to be similar to 15 and 16 years old center back players from Slovenia, Turkey, Serbia and Greece national teams (Ozkol et al., 2010).

The Portuguese outside or peripheral players were significantly different in muscle mass as compared to their counterparts on the Spanish team. The Portuguese players had shorter arm spans and lower training hours per week, which likely contributed to inequities in competitive levels between these two national teams. The outside players, particularly wingers, must develop organized attacks and man-up strategies, trying to end them with a powerful throw, what points out the importance of muscle mass parameters. Additionally, outside players aim to release the counterattack, swim longer distances with greater intensity during a game (Hughes et. al., 2006). Such role characteristics require proper training. In turn, they do not need a very high stature to perform their tasks during the game (Hughes et al., 2006; Lozovina et al., 2009). From this point of view, Portuguese outside players' tendency for lower values of body height would not be considered disadvantageous. However, outside players also need to perform the defensive block, a skill that is related with the success of elite teams (Hughes et al., 2006; Takagi et al., 2005); therefore, having a high arm span can be important.

Body fat and body mass index parameters, although found to be similar between the players from both teams, were lower than those reported in the literature for elite senior players (Melchiorri et al., 2010; Tsekouras et al., 2005). In addition, the values of body mass index of Portuguese players tend to be similar to the values reported for the 71 players from junior national teams of Slovenia, Turkiye, Serbia and Greece (Ozkol et al., 2010). In turn, Spanish players presented body mass index similar to senior elite players (Tsekouras et al., 2005) and higher than for junior players (Ozkol et al., 2010). For Dopsaj and Aleksandrović (2009), it seems that fat percentage and a higher body mass index values are not a limiting factor for efficiency in waterpolo game. Instead, in hydrostatic and hydrodynamic terms, a bigger body volume provides better conditions for its floatability. 
Regarding the somatotype (Table 2 and Figure 1), both Spanish and Portuguese players are classified as endo-mesomormorphs, which is similar to data reported in the literature (Carter \& MarfellJones, 1994; Platanou \& Nikolopoulos, 2003). The high strength levels of water polo players are very important for their performance. This is confirmed by the predominance of mesomorphic component in their somatotype which is a characteristic of elite players (Vila et al. 2010). However, the plots of the somatochart depict the placement of all Portuguese players below the Spanish players. This indicates that they have a tendency toward lower muscle-skeletal development. Indeed, in the somatotype components (Table 2), Spanish players show a tendency for higher mesomorphic values in general and by playing positions than the Portuguese players. Furthermore, in Portuguese team, the outside and center back players are plotted near each other and near to all Portuguese players, showing a lack of anthropometrical distinction between those field positions. Moreover, Portuguese goalkeepers' plots show a distinct place in the somatochart. Additionally, their ectomesomorphic classification differs from Spanish goalkeepers (classified as balanced mesomorphs). Although the Portuguese goalkeepers linearity can be considered a positive attribute for that specific position (Kačić, 2007), their ectomorphic component is relative. As it can be observed in Figure 1, Portuguese goalkeepers tend to have lower values of arm span $(10 \mathrm{~cm})$ than their Spanish counterparts and also lower body height. This information, associated with the lower muscle mass percentage, confirms their tendency for having less muscle-skeletal mass.

Carter and Marfell-Jones (1994) explain that water sports players are predominantly mesomorphic. Indeed, the Spanish players were more mesomorphic than were the Portuguese players. Our findings for the mesomorphic component in the Spanish center forwards and center backs corroborated those found by Platanou and Nikolopoulos (2003). Center backs and center forwards present a tendency for higher values of mesomorphic component than the other positions. They have a greater volume and muscle-skeletal development, which is in line with the physical requirements for those particular positions. However, Portuguese center backs are balanced mesomorphs and are placed at the center of the somatochart. They have a tendency for lower volume, while their center forwards peers are classified the same way (endo-mesomorphs) as the Spanish counterparts and in agreement with findings from the literature.

The Spanish and Portuguese outside players differ in their classification and the later tend to present an endomorphic value superior to the ectomorphic one (classified as endo-mesomorphs). The Spanish players are more balanced (classified as balancedmesomorphs). The mesomorphic component between both teams differ in 1.0 (Carter \& Marfell-Jones, 1994), showing tendency for less muscle-skeletal development by the Portuguese outside players with plotted point beneath their Spanish counterparts. This somatotype aspect is in agreement with the already proven significant difference of muscle mass between the outside players of the two studied teams. As Lima et al. (2007) states, the knowledge about the morphological patterns can contribute positively not only for the players' selection, but also for determining their roles within the team and for coaches' decisions concerning a suitable plans and specific training protocol.
The findings herein confirm the study's hypothesis and highlight the differences in morphology and training background between two teams with different competitive level in waterpolo. Also the study emphasizes the supremacy of Spaniards in relation to Portuguese for most of the studied parameters. Regarding specific positions and particularly in what concerns the center players, the differences of physical size between the two teams can be outstanding. Spaniards perform almost twice the number of training hours per week. Furthermore, the fact that Spanish group belongs to a elite team has direct implication in terms of a higher exposure of their players to challenging and real playing situations, requiring the performance in each position of play, which are also accumulated in specific training volume over the years. These evidences provide information to clarify some of the reasons why competitive level, success and performance between the two studied groups are so different. The evidences from this study justify the importance of body height, body mass and arm span when electing the selection criteria for recruiting waterpolo players with the goal of attaining a higher level team. However, it would be important to undertake further investigations about this issue with other teams to enhance the scientific contribution for the improvement of the waterpolo sport.

\section{References}

Aleksandrović, M., Naumovski, A., Radovanović, D., Georgiev, G., \& Popovski, D. (2007). The influence of basic motor abilities and anthropometric measures on the specific motor skills of talented water polo players. Facta Universitatis Series Physical Education And Sport, 5, 65-74.

Carter, J.E.L., \& Ackland, T.R. (Eds). (1994). Kinanthropometry in aquatic sports: A study of world class athletes. Campaign, IL: Human Kinetics.

Carter, J.E.L., \& Marfell-Jones, M.J. (1994). Somatotype. In J.E.L. Carter, \& T.R. Ackland (Eds), Kinanthropometry in aquatic sports - A study of world class athletes (pp.55-82). Campaign, IL: Human Kinetics.

Donev, Y., Mtan, A., Nikolova, M., Bačev, V., \& Aleksandrović, M. (2009). Basic distinctions in factor structure of the specific workability of 13-14 Years old Syrian water polo players under the conditions of one and two cycle planning of the year training sessions. Sport Science, 2, 24-30.

Dopsaj, M., \& Thanopoulos, V. (2006). The structure of evaluation indicators of vertical swimming work ability of top water polo players. Portuguese Journal of Sport Sciences, 6, 124-125.

Dopsaj, M., Madić, D., \& Okičić, T. (2007). The assessment of the acquisition of various crawl style modes in water polo players with respect to age and competitive levels. Series Physical Education and Sport, 5, 109-120.

Dopsaj, M., \& Aleksandrović M. (2009). Basic anthropomorphological characteristics of elite senior Serbian water polo players according to field position. International Journal of Fitness, 5, 47-57.

Drinkwater, D.T., \& Mazza, J.C. (1994). Body Composition. In J.E.L. Carter, \& T.R. Ackland (Eds), Kinanthropometry in aquatic sports - A study of world class athletes (pp.102-137). Campaign, IL: Human Kinetics.

Escalante, Y., Saavedra, J.M., \& Mansilla M. (2011). Discriminatory power of water polo game-related statistics at the 2008 Olympic Games. Journal of Sport Sciences, 29, 291-298. 
Falk, B., Lidor, R., Lander, Y., \& Land, B. (2004). Talent identification and early development of elite water polo players: A 2-year follow -up study. Journal of Sport Sciences, 22, 347-355.

Garbolewski, K., \& Starosta, W. (2002). Level and conditions of selected motor co-ordinations and jumping abilities among advanced water-polo players. Journal of Human Kinetics, 8,17-21.

Hughes, M., Appleton, R., Brooks, C., Hall, M., \& Wyatt, C. (2006). Notational analysis of elite men's water-polo. In H. Dancs, M. Hughes \& P. O'Donoghue (Eds.), Proceedings of World Congress on Performance Analysis of Sport 7 (pp.137-159). Hungary: Berzsenyi College, Szombathely.

Kačić, Z. (Ed). (2007). Water polo Goalkeeper. Split: Split Univer.

Lima, L.R., Sigwalt, A.R, Rech, C.R., \& Petroski, E.L.(2007). Somatotype and body composition of water polo female athletes from Brazil. Revista da Educação Física/UEM, Maringá, 18, 191-198.

Lozovina, V., \& Pavičić, L. (2004). Anthropometric changes in elite male water polo players: Survey in 1980 and 1995. Croatian Medical Journal, 45, 202-205.

Lozovina, M., Durović, N., \& Katić, R. (2009). Position specific morphological characteristics of elite water polo players. Collegium Antropologicum, 33, 781-789.

Lupo, C., Tessitore, A., Minganti, C., \& Capranica L. (2010). Notational analysis of elite and sub-elite water polo matches. Journal of Strength and Condition Research, 24, 223-229.

Martin, A.D., Spenst, L.F., Drinkwater, D.T., \& Clarys J.P. (1990). Anthropometric estimation of muscle mass in men. Medicine and science in sports and exercise, 22, 729-733.

Melchiorry, G., Padua, E., Sardella, F., Manzi, V., Tancredi, V., \& Bonifazi, M. (2010). Physiological profile of water polo players in different competitive levels. Journal of Sports Medicine and Physical Fitness, 50, 19-24.

Ozkol, Z., Dopsaj, M., Thanopoulos. V., \& Bratusa, Z. (2010). Models for Assessing General Horizontal Swimming Abilities of Junior water polo Players According to Playing Position. In P.L. Kjendlie, R.K. Stallman, \& J. Cabri (Eds.), Proceedings of the XIth International Symposium for Biomechanics and Medicine in Swimming (pp.276-278).Oslo: Norwegian School of Sport Science.

Platanou, T. (2004). Time-Motion Analysis of International level Water polo Players. Journal of Human Movement Studies, 46, 319-331.

Platanou, T. (2009). Physiological demands of water polo goalkeeping. Journal of Science and Medicine in Sport, 12, 244 -250.

Platanou, T., \& Geladas, N. (2006). The influence of game duration and playing position on intensity of exercise during match-play in elite water polo players. Journal of Sport Sciences, 24, 1173-1181.

Platanou, T., \& Nikolopoulos, G. (2003). Physiological demands of water polo games with different levels of competitiveness. In J.C. Chatard (Ed.), Proceedings of the IXth International Symposium for Biomechanics and Medicine in Swimming (pp. 493-498). Saint-Etienne: Univer. of Saint Etienne.

Ross, W.D., \& Marfell-Jones, M.J. (1991). Kinanthropometry. In D. MacDougall, H. Wenger, \& H. Green (Eds), Physiological testing of the high-performance athlete (pp. 22-29). Campaign, IL: Human Kinetics.

Takagi, H., Nishijima, T., Enomoto, I., \& Stewart, A.M. (2005). Determining factors of game performance in the 2001 world Water polo Championships. Journal of Human Movement Studies, 49, 333-352.

Tsekouras, Y.E., Kavouras, S.A., Campagna, A., Kotsis, Y.P., Syntosi, S.S., Papazoglou, K., \& Sidossis, L.S. (2005). The anthropometrical and physiological characteristics of elite water polo players. European Journal of Applied Physiology, 95, 35-41.

Vila, M.H., Ferragut, C., Rodrigues, N., Argudo, F., \& Abraldes, A. (2010). Anthropometric characteristics, body composition and somatotype of elite players in water polo. Revista Brazileira de Ciências do Esporte, Florianópolis, 32, 185-197.
Yuhasz, M.S. (1974). Physical Fitness Manual. London, Ontario: University of Western Ontario.

\section{Authors' note}

Sofia Canossa, Susana Soares, Júlio Manuel Garganta and Ricardo Jorge Fernandes are affiliated with the Center of Research, Education, Innovation and Intervention in Sport $\left(\mathrm{CIFI}^{2} \mathrm{D}\right)$, Faculty of Sport, University of Porto, Portugal. Ricardo Jorge Fernandes is also affiliated with the Laboratory of Biomechanics of Porto (LABIOMEP), Faculty of Sport, University of Porto, Portugal.

José Arturo Abraldes is affiliated with the Faculty of Sports Sciences, University of Murcia, UMU, Spain.

María Helena Vila is affiliated with the Faculty of Education and Sports Sciences, University of Vigo, Spain.

Carmen Ferragut is affiliated with the Faculty Physical Activity and Sport Studies, University of Alcalá, Spain.

Nuria Rodríguez is affilieated with the Faculty of Sport Sciences, Catholic University of Murcia, Spain.

Francisco Manuel Argudo is affiliated with the Faculty of Education and Teacher Formation, Autonomous University of Madrid, Spain.

\section{Acknowledgments}

We would like to thank the funding support from Spanish Government grant DEP 2008-06114 I+D to the Spanish and Portuguese water polo national teams, and to the Portuguese Swimming Federation and to the Swimming Association of the North of Portugal. This study is part of a doctoral dissertation.

\section{Corresponding author}

Ricardo J. Fernandes

Laboratory of Biomechanics of Porto (LABIOMEP) and Center of Research, Education, Innovation and Intervention in Sport (CIFI $\left.{ }^{2} \mathrm{D}\right)$, Faculty of Sport, University of Porto.

Rua Plácido Costa, 91. 4200 Porto, Portugal

Telephone: +351 (22) 5074762

Fax: +351 (22) 5500689

E-mail: ricfer@fade.up.pt

Manuscript received on August 30, 2013

Manuscript accepted on June 24, 2014

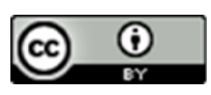

Motriz. The Journal of Physical Education. UNESP. Rio Claro, SP, Brazil - eISSN: 1980-6574 - under a license Creative Commons - Version 3.0 